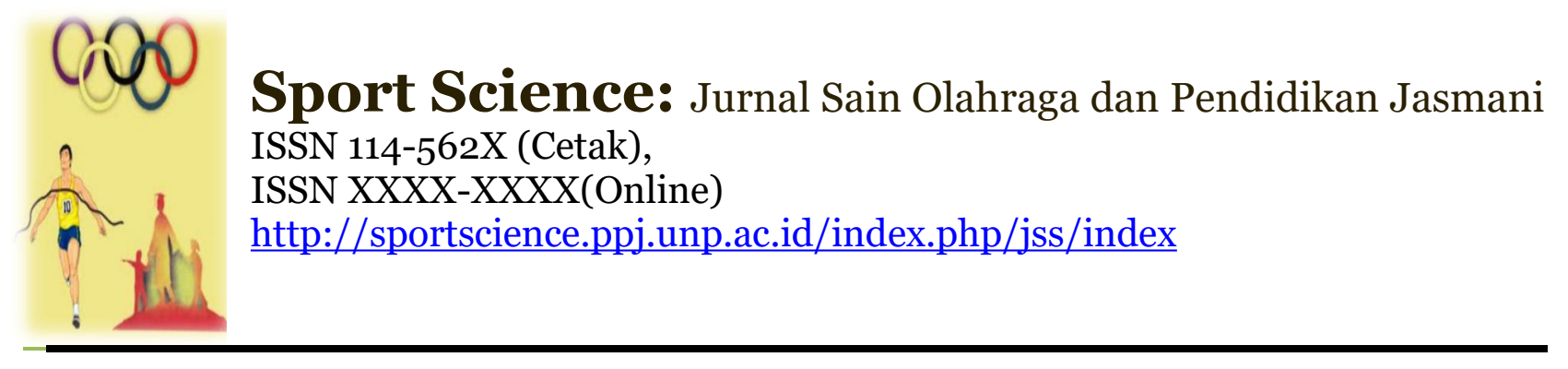

\title{
Pengaruh Latihan Overhead Tricep Toss terhadap Peningkatan Daya Ledak Otot Lengan Pemain Bolavoli
}

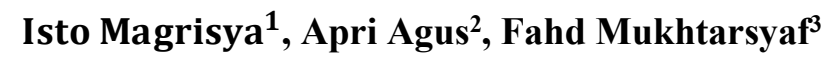 \\ ${ }^{123}$ Fakultas Ilmu Keolahragaan, Universitas Negeri Padang, Indonesia. \\ E-mail: $\underline{\text { istomagrisya@gmail.com }}{ }^{1}$, apriagus@,fik.unp.ac.id², fahd@fik.unp.ac.id
}

\begin{abstract}
Abstrak
Masalah dalam penelitian ini berawal belum maksimalnya daya ledak otot lengan pemain bolavoli SMA Model Negeri 04 Mukomuko. Penelitian ini bertujuan untuk mengetahui pengaruh latihan overhead tricep toss terhadap peningkatan daya ledak otot lengan pemain bolavoli SMA Model Negeri 04 Mukomuko.

Jenis penelitian ini adalah eksperimen semu.Populasi dalam penelitian ini yaitu seluruh pemain bolavoli SMA Model Negeri 04 Mukomukoyang berjumlah 20 orang. Teknik pengambilan sampel menggunakan purposive sampling. Dengan demikian jumlah sampel di dalam penelitian ini adalah 12 orang pemain putra. Teknik pengambilan data dengan two hand medicine ball put. Data di analisis dengan uji statistik beda rerata hitung (t-test) pada taraf signifikansi $\alpha=0.05$.

Hasil analisis menyatakan bahwa terdapat peningkatan daya ledak otot lengan setelah diberi perlakukan. Dengan demikian dapat disimpulkan bahwa latihan overhead tricep tossmemberikan pengaruh yang berarti terhadap peningkatan daya ledak otot lengan pemain bolavoli SMA Model Negeri 04 Mukomuko, yang dibuktikan dengan $t_{\text {hitung }}=15,923>t_{\text {tabel }}=2,201$ dengan $\alpha=0.05$.
\end{abstract}

Kata Kunci: Latihan overhead tricep toss, daya ledak otot lengan, bolavoli

\begin{abstract}
The problem in this research was not yet maximal the muscle explosive power of volley ball player SMA Negeri Mukomuko. This study aims to determine the effect of overhead tricep toss training on improving the muscle explosive power of the high school volley ball player Model Negeri 04 Mukomuko.

This type of research is a quasi experiment. The population in this study is the entire player volley ball SMA Negeri Negeri Mukomuko which amounted to 20 people. Sampling technique using purposive sampling. Therefore the number of samples in this study is 12 men players. Technique of taking data with two hand medicine ball put. The data were analyzed by statistical test of $\mathrm{t}$-test at significance level $\alpha=0.05$.

The results of the analysis suggest that there is an increase in arm muscle burst power after being treated. Thus it can be concluded that the tricep toss overhead exercise has a significant effect on the improvement of muscular explosive power of the SMA Negeri Mukomuko Model SMA bolavoli player, as evidenced by $t_{\text {hitung }}=15,923>t_{\text {tabel }}=2,201$ which $\alpha=0.05$.
\end{abstract}

Keywords: Exercise overhead tricep toss, explosive arm muscle power, volley ball 


\section{PENDAHULUAN}

Dalam pembangunan bangsa Indonesia pada dasarnya mengarah pada peningkatan kualitas manusia Indonesia. Sedangkan pembinaan olahraga merupakan bagian dari upaya peningkatan kualitas tersebut. Sekarang kita hidup pada zaman globalisasi dimana pembangunan disegala bidang. Dalam pembangunan ini kita harus mengembangkan dan membina kegiatan olahraga, baik olahraga untuk kebugaran maupun olahraga untuk mencapai prestasi.

Olahraga prestasi adalah olahraga yang membina dan mengembangkan olahragawan secara terencana, berjenjang dan berkelanjutan melalui kompetensi untuk mencapai prestasi dengan dukungan dan ilmu pengetahuan dan teknologi olahraga, untuk pengembangan dan peningkatan prestasi olahraga maka adanya dukungan dari pemerintah. Melalui prestasi olahraga bangsa Indonesia bisa dikenal oleh bangsa lain. Hal tersebut sesuai dengan Undang-Undang Republik Indonesia Nomor 3 Tahun 2005 tentang Sistem Keolahragaan Nasional, Pasal 4 tentang dasar dan fungsi dan tujuan olahraga yaitu:"Keolahragaan nasional bertujuan memelihara dan meningkatkan kesehatan dan kebugaran, prestasi, kualitas manusia, menanamkan nilai moral dan akhlak mulia, sportivitas, disiplin, mempererat dan membina persatuan dan kesatuan bangsa, memperkukuh ketahanan nasional, serta mengangkat harkat, martabat, dan kehormatan bangsa"

Berdasarkan kutipan di atas, jelaslah bahwa salah satu tujuan keolahragaan nasional adalah meningkatkan prestasi, khususnya prestasi dalam bidang olahraga. Prestasi olahraga ini dapat dicapai tentunya melalui pengembangan dan pembinaan. Pengembangan dan pembinaan olahraga merupakan terobosan untuk meningkatkan olahraga prestasi. Prestasi olahraga dilakukan oleh setiap orang yang memiliki bakat, kemampuan dan potensi untuk mencapai prestasi tersebut. Menurut Syafruddin (2008:5)"Olahraga prestasi adalah olahraga yang membina dan mengembangkan olahragawan secara terencana, berjenjang dan berkelanjutan melalui latihan dan kompetisi untuk mencapai prestasi dengan dukungan ilmu pengetahuan dan teknologi keolahragaan".

Berpedoman pada kutipan di atas, maka dapat ditarik suatu kesimpulan bahwa olahraga prestasi merupakan olahraga yang dipertandingkan, dalam pembinaannya harus dilakukan secara berkesinambungan melalui latihan-latihan yang terencana, terprogram dan di dukung oleh olahraga yang berkontribusi pada keolahragaan yang artinya pengembangaan olahraga prestasi bagi olahragawan harus mengacu pada tujuan yang hendak dicapai, yaitu yang mampu bersaing diarena pertandingan atau kompetisi baik ditingkat daerah maupun di tingkat nasional.

Permainan Bolavoli merupakan salah satu cabang olahraga permainan beregu, yang dimainkan dua regu yang masing-masing regu terdiri dari enam pemain, maka antara pemain harus bekerja sama dan saling mendukung agar menjadi regu yang kompak dan tangguh. Permainan Bolavoli dimainkan pada lapangan yang berukuran panjang 18 meter dan lebar 9 meter, dengan tinggi net 2,43 meter untuk putera dan 2,24 meter untuk puteri. Permainan ini melibatkan hampir semua bentuk gerakan yang bersifat melompat, memukul dan gerakan eksplosif lainnya. Pada dasarnya permainan Bolavoli mempunyai prinsip penyerangan dan bertahan.

Permainan Bolavoli di kenal di Indonesia sejak tahun 1928. Sejak PON II di Jakarta pada tahun 1948 sampai sekarang, Bolavoli termasuk salah satu cabang olahraga resmi dipertandingan (Yunus, 1992:7). Perkembangan permainan Bolavoli di Indonesia nampak maju dengan pesat sejak persiapan menghadapi Asean Games IV dan Ganefo I di Jakarta. Organisasi Bolavoli Indonesia itu terbentuk atas prakarsa Ikatan Bolavoli Surabaya (IBVOS) dan Persatuan Voli Indonesia Jakarta (PERVID). Pada tanggal 22 Januari 1955, bebepa tokok Bolavoli Indonesia di stadion Ikada. Rapat 
Sport Science: Jurnal Sain Olahraga dan Pendidikan Jasmani ISSN 114-562X (Cetak), ISSN XXXX-XXXX(Online)

http://sportscience.ppj.unp.ac.id/index.php/jss/index

tersebut menghasilkan keputusan, yaitu terbentuknya organisasi Bolavoli nasional dengan nama Persatuan Bolavoli Seluruh Indonesia (PBVSI) (Beutelstahl, 2003:2). Dengan pesatnya perkembangan Bolavoli di tingkat nasional maka timbul keinginan dari berbagai pelosok untuk membangun klub agar dapat bisa mengikuti pertandingan di tingkat nasional.

Mukomuko merupakan salah satu Kabupaten di Provinsi Bengkulu yang sangat peduli terhadap pembinaan olahraga Bolavoli, secara berkesinambungan dengan tujuan mendapatkan bibit berpotensi yang siap membawa nama daerah ke tingkat nasional maupun internasional. Pengembangan pembinaan olahraga ini dilaksanakan mulai dari pendidikan di Sekolah Dasar, Sekolah Menengah pertama, sekolah menengah atas, perguruan tinggi dan pada masyarakat.

Untuk mencapai prestasi dalam permainan Bolavoli sangat perlu adanya pembinaan secara serius sejak usia dini harus terus dilakukan, salah satunya melalui jalur pendidikan. Lembaga pendidikan dapat digunakan untuk melakukan pembinaan prestasi olahraga dikarenakan muatan kurikulum pendidikan jasmani di sekolah juga memuat pokok bahasan permainan Bolavoli termasuk pembinaan prestasi yang dilakukan melalui kegiatan ekstrakurikuler.

SMA Model Negeri 04 Mukomuko adalah salah satu sekolah yang berada di Kabupaten Mukomuko yang melaksanakan kegiatan ekstrakurikuler dalam pembinaan cabang olahraga Bolavoli, dimana kegiatan ekstrakurikuler ini dilaksanakan diluar jam mata pelajaranan yaitu dengan dua kali tatap muka perminggu yang jadwal latihannya sudah diprogramkan oleh pelatih. Ekstrakurikuler ini merupakan program sekolah, berupa kegiatan siswa yang bertujuan memperdalam dan memperluas pengetahuan siswa, optimalkan pelajaran yang terkait, menyalurkan bakat dan minat, kemampuan dan keterampilan serta untuk lebih memantapkan kepribadian siswa.

Didalam pengembangan kegiatan ekstrakurikuler disekolah tidak terlepas dari motivasi yang diberikan oleh para pembina kegiatan ekstrakurikuler, ini tentunya tidak terlepas dari latihan-latihan dan didukung oleh program latihan yang dilakukan secara terarah dan terpadu yang dilakukan secera terus menerus sehingga pemain atau siswa dapat mememiliki kemampuan teknik dasar bermain Bolavoli yang baik serta dapat meraih prestasi.

Dalam pembinaan untuk meraih sebuah prestasi dalam permainan Bolavoli perlu didukung oleh kondisi fisik, teknik, taktik dan mental yang baik. Hal ini sesuai dengan pendapat Syafruddin (2011:57) bahwa "Keberhasilan prestasi yang ditunjukkan/ditampilkan seorang atlet dalam suatu kompetisi terutama ditentukan dan dipengaruhi oleh kemampuan atau potensi atlet itu sendiri secara terpadu, baik kemampuan fisik, teknik, taktik, dan mental”. Oleh karena itu, untuk memenuhi prestasi atlet harus memiliki empat komponen prestasi yang baik.

Berdasarkan informasi dari pelatih bolavoli SMA Model Negeri 04 Mukomuko yaitu Bapak Doni Ashandika S.Pd pada tanggal 23 Februari 2017, prestasi bolavoli masih rendah. Hal ini dapat dilihat dari iven-iven yang pernah diikuti SMA Model Negeri 04 Mukomuko, diantaranya pada tahun 2015 mengikuti O2SN tingkat Kabupaten, hanya masuk 4 besar, pada tahun 2015 mengikuti pertandingan Bupati Cup hanya sampai babak penyisihan, sedangkan tahun 2016 mengikuti pertandingan HUT Kabupaten Mukomuko, hanya masuk 8 besar, pada tahun 2017 mengikuti O2SN, sekolah tersebut hanya sampai babak penyisihan.

Berdasarkan observasi dan pengamatan yang penulis lakukan dilapangan terhadap pemain bolavoli SMA Model Negeri 04 Mukomuko salah satu penyebab kurangnya prestasi SMA Model 
Negeri 04 Mukomuko disebabkan daya ledak otot lengan pemain belum baik, hal ini terlihat ketika melakukan smash, pukulan yang dilakukan pemain tidak keras, tidak tajam, tidak mematikan, serta kurang terarah sehingga lawan mudah mengembalikan bola, ini salah satu faktor yang menyebabkan angka bertambah untuk lawan, kondisi ini tentunya akan menguntungkan bagi pihak lawan untuk memperoleh poin. Dari permasalahan tersebut diduga ada beberapa faktor yang menyebabkan belum baiknya daya ledak otot lengan pemain bolavoli SMA Model Negeri 04 Mukomuko, diantaranya disebabkan oleh faktor internal dan eksternal seperti kurang kondisi fisik, metode latihan, pelatih, program, sarana dan prasarana

Berdasarkan hasil tes daya ledak otot lengan dengan menggunakan bola medicane yang dilakukan terhadap 12 pemain bolavoli SMA Model Negeri 04 Mukomuko, tidak ada pemain yang memiliki daya ledak otot lengan dengan kategori baik sekali, 2 orang (16.67\%) kategori baik, 9 orang (75\%) kategori sedang, 1 orang (8.33) dan tidak ada pemain yang memiliki daya ledak otot lengan dengan kategori kurang sekali. Secara keseluruhan daya ledak otot lengan pemain bolavoli SMA Model Negeri 04 Mukomuko berada pada kategori "Sedang"

Daya ledak otot lengan merupakan salah satu komponen dasar kondisi fisik yang sangat penting dalam olahraga bolavoli, terutama sekali saat melakukan smash. Jika seorang pemain tidak memiliki daya ledak otot lengan yang bagus saat melakukan smash, tentunyabola yang dipukul tidak kuat dan mudah untuk dikembalikan oleh lawan. Smash dalam permainan bolavoli merupakan pukulan bola tajam ke bawah dengan kecepatan yang keras.

Menurut informasi dari pelatih dan beberapa pemain bolavoli SMA Model Negeri 04

Mukomuko diperoleh gambaran bahwa penyebab kegagalan pemain dalam melakukan smash salah satunya kondisi fisik pemain yang masih belum baik, terutama sekali daya ledak otot lengan. Ternyata pemain bolavoli SMA Model Negeri 04 Mukomuko kurang melakukan bentuk-bentuk latihan untuk meningkatkan daya ledak otot lengan dan belum melakukan latihan dengan efektif.

Bertolak dari uraian di atas tampak permasalahan yang akan diteliti bahwa dalam melakukan smash dibutuhkan unsur daya ledak otot lengan. Semakin bagus daya ledak otot lengan maka semakin kuat pukulannya. Untuk meningkatkan daya ledak otot lengan dibutuhkan program latihan yang baik, terencana, terprogram sehingga tercapainya yang diinginkan. Untuk meningkatkan daya ledak otot lengan banyak metode latihan yang dapat digunakan. Menurut McNeely (2007:111) Bentuk latihan untuk meningkatkan daya ledak otot lengan dengan menggunakan bola medicine adalah Overhead tricep toss

Latihan ini dilakukan dengan cara menggenggam bola dengan satu tangan lurus di samping kepala, setelah itu bengkokan lengan sehingga siku mengarah lurus kedepan dan tegak lurus terhadap tanah dimana bola berada dibelakang kepala, kemudian luruskan lengan secepat mungkin dan lempar bola ke udara dengan hanya menggunakan otot tricep. Latihan ini dilakukan dengan menggunakan bola medicine sebagai beban dan melakukan lemparan, operan/ pemindahan dengan bola tersebut. Berdasarkan uraian tersebut peneliti tertarik untuk melakukan penelitian tentang sejauh mana pengaruh latihan overhead tricep toss terhadap peningkatatan daya ledak otot lengan pemain bolavoli SMA Model Negeri 04 Mukomuko.

\section{METODE}

Jenis penelitian ini adalah eksperimen. Menurut Riduwan (2005:50) Penelitian experimen adalah "suatu penelitian yang berusaha mencari pengaruh variabel tertentu terhadap variabel yang lain dalam kondisi yang terkontrol secara ketat". Adapun variabel bebasnya adalah latihan overhead tricep toss $(\mathrm{X})$, sedangkan variabel terikatnya adalah kemampuan daya ledak otot lengan (Y). Penelitian ini dilaksanakan di SMA Model Negeri 04 Mukomuko, sedangkan penelitian dilaksanakan pada bulan 
Agustus-September 2017. Populasi adalah keseluruhan subyek yang diselidiki”. Dengan demikian populasi dalam penelitian ini adalah seluruh pemain bolavoli SMA Model Negeri 04 Mukomuko yang berjumlah 20 orang.

Untuk lebih jelas dapat dilihat pada tabel 1.Sampel adalah sebahagian atau wakil dari populasi yang diteliti. Teknik pengambilan sampel dalam penelitian ini adalah purposive sampling. Menurut Arikunto purposive sampling (2010:183) dilakukan dengan cara mengambil subjek bukan atas strata, random, atau daerah tapi didasarkan atas tujuan tertentu, dimana yang dijadikan sampel adalah atlet putra, karena sering dan rutin mengikuti latihan dan mengikuti pertandingan. Dengan demikian jumlah sampel dalam penelitian ini berjumlah 12 orang putra.Instrumen penelitian adalah alat pada waktu penelitian menggunakan suatu teknik untuk mengumpulkan data dari peningkatan daya ledak otot lengan.

Untuk mengukur daya ledak otot lengan dari pemain digunakan tes two hands medicine ball put (Ismaryati,2006:64). Dalam penelitian ini data dapat diolah dengan menggunakan statistik deskriptif dan inferensial. Dengan menggunakan rumus uji t. Sebelum analisis uji $t$ digunakan terlebih dahulu dilakukan uji normalitas data. Karena uji t hanya dapat digunakan untuk menguji perbedaan mean. Dari dua sampel yang di ambil dari populasi yang normal.

\section{HASIL DAN PEMBAHASAN \\ Hasil Penelitian}

Berdasarkan hasil tes daya ledak otot lengan dengan lempar bola medicine dengan dua tangan sebelum diberi perlakuan latihan overheadtricep toss terhadap 12 orang pemain bolavoli SMA Model Negeri 04 Mukomuko, diperoleh rata-rata adalah 3.8, standar deviasi adalah 0.48, nilai maksimum 4.78 dan nilai minimumnya 3.22 .

Tabel 1. Distribusi Frekuensi Data Daya Ledak Otot Lengan Sebelum Latihan OverheadTricep Toss

\begin{tabular}{clccc}
\hline No & Klasifikasi & Kelas interval & $\begin{array}{l}\text { Frekuensi } \\
\text { Absolut }\end{array}$ & $\begin{array}{c}\text { Frekuensi } \\
\text { Relatif ( \%) }\end{array}$ \\
\hline 1 & Baik sekali & $>7,92$ & 0 & 0 \\
2 & Baik & $6,71-7,62$ & 0 & 0 \\
3 & Sedang & $4,27-6,10$ & 2 & 16.67 \\
4 & Kurang & $3,05-4,66$ & 10 & 83.33 \\
& Kurang & $0-2,74$ & 10 & 0 \\
5 & sekali & & $\mathbf{1 2}$ & $\mathbf{1 0 0}$ \\
\multicolumn{2}{c}{ Jumlah } & & & \\
\hline
\end{tabular}

Dapat dilihat bahwa dari 12 pemain bolavoli SMA Model Negeri 04 Mukomuko, tidak ada pemain yang memiliki daya ledak otot lengan dengan klasifikasi baik sekali dan baik, 2 orang $(816.67 \%)$ pemain yang memiliki daya ledak otot lengan klasifikasi sedang, 10 orang $(83.33 \%)$ pemain yang memiliki daya ledak otot lengan klasifikasi kurang, dan tidak ada pemain yang memiliki daya ledak otot lengan klasifikasi kurang sekali. Secara keseluruhan daya ledak otot lengan pemain bolavoli SMA Model Negeri 04 Mukomuko berada pada klasifikasi "Kurang" yang dibuktikan dengan nilai rata-rata 3,8. Berdasarkan hasil tes daya ledak otot lengan dengan lempar bola medicine dengan dua tangan setelah diberi perlakuan latihan overheadtricep toss terhadap 12 orang pemain bolavoli SMA Model Negeri 04 Mukomuko, diperoleh rata-rata adalah 4.3 standar deviasi adalah 0.46 nilai maksimum 5.14 dan nilai minimumnya 3.65.

Tabel 2. Distribusi Frekuensi Data Daya Ledak Otot Lengan Sesudah Latihan OverheadTricep Toss 


\begin{tabular}{clccc}
\hline No & Klasifikasi & Kelas interval & $\begin{array}{l}\text { Frekuensi } \\
\text { Absolut }\end{array}$ & $\begin{array}{l}\text { Frekuensi } \\
\text { Relatif ( \%) }\end{array}$ \\
\hline 1 & Baik sekali & $>7,92$ & 0 & 0 \\
2 & Baik & $6,71-7,62$ & 0 & 0 \\
3 & Sedang & $4,27-6,10$ & 5 & 41,67 \\
4 & Kurang & $3,05-4,66$ & 7 & 58,33 \\
5 & Kurang sekali & $0-2,74$ & 0 & 0 \\
Jumlah & & $\mathbf{1 2}$ & $\mathbf{1 0 0}$ \\
\hline
\end{tabular}

Dapat dilihat bahwa dari 12 pemain bolavoli SMA Model Negeri 04 Mukomuko, tidak ada pemain yang memiliki daya ledak otot lengan dengan klasifikasi baik sekali dan baik, 5 orang (41.67\%) pemain yang memiliki daya ledak otot lengan klasifikasi sedang, 7 orang $(58.33 \%)$ pemain yang memiliki daya ledak otot lengan klasifikasi kurang dan tidak ada pemain yang memiliki daya ledak otot lengan klasifikasi kurang sekali. Secara keseluruhan daya ledak otot lengan pemain bolavoli SMA Model Negeri 04 Mukomuko berada pada klasifikasi "Sedang" yang dibuktikan dengan nilai rata-rata 4.3.

Sebelum melakukan pengujian terhadap hipotesis yang diajukan dalam penelitian ini, maka terlebih dahulu di lakukan uji persayaratan analisis dengan uji normalitas data untuk mengetahui apakah data dari variabel yang diteliti berdistribusi normal atau tidak. Uji normalitas variabel menggunakan Liliefort, menunjukkan bahwa data tidak berbeda nyata, Lo $<$ Ltabel, artinya data tersebut berdistribusi normal. Hasil lengkap Liliefort dapat dilihat pada tabel 5.

Tabel 3. Uji Normalitas Data Penelitian

\begin{tabular}{|c|c|c|c|c|c|}
\hline Variabel & & $\mathbf{N}$ & Lo & Ltabel & Keterangan \\
\hline & Sebelum & 12 & 0.215 & 0.242 & Normal \\
\hline Daya Ledak & Perlakukan & & & & \\
\hline Otot Lengan & $\begin{array}{l}\text { Setelah } \\
\text { Perlakuan }\end{array}$ & 12 & 0.214 & 0.242 & Normal \\
\hline
\end{tabular}

Berdasarkan pada tabel 3 ternyata hasil Liliefort, menunjukan bahwa Lo < Ltabel, dengan demikian dapat disimpulkan bahwa kedua data, yaitu daya ledak otot tungkai selum dan sesudah perlakukan latihan overheadtricep toss terhadap peningkatan daya ledak otot lengan pemain bolavoli SMA Model Negeri 04 Mukomuko berdistribusi normal dan layak untuk dilanjutkan. Pengujian homogenitas dilakukan dengan uji varians. Syarat ini berkenaan untuk menunjukkan bahwa data mempunyai keragaman/ kesamaan varians. Artinya varians data populasi sama, data dalam keadaan homogen. Rangkuman hasil pengujian kesamaan varians tersebut disajikan pada tabel 6 .

Tabel 4. Uji Homogenitas

\begin{tabular}{llll}
\hline Variabel & $\mathbf{F}_{\text {hitung }}$ & $\mathbf{F}_{\text {tabel }}$ & Kesimpulan \\
\hline Daya Ledak Otot Lengan & 1.09 & 2.85 & Homogen \\
\hline
\end{tabular}

Berdasarkan tabel 4 ternyata $F_{\text {hitung }}(1.09)<\mathrm{F}_{\text {tabel }}$ (2.85), maka dapat disimpulkan bahwa kedua varians tersebut homogen. Dengan kata lain dapat disimpulkan bahwa kedua kelompok sampel tersebut berasal dari populasi yang homogen.

Hipotesis yang diajukan di dalam penelitian ini adalah terdapat pengaruh latihan overheadtricep toss terhadap peningkatan daya ledak otot lengan pemain bolavoli SMA Model Negeri 04 Mukomuko. Untuk menguji koefisien hipotesis digunakan Uji - t. Sedangkan untuk menentukan apakah kofisien $t$ yang diperoleh dengan rumus thitung tersebut signifikan atau tidak maka dibandingkan dengan rumus $t_{\text {tabel. }}$ 
Berdasarkan hasil analisis koefisien tersebut diperoleh $t_{\text {hitung }}=15,923>t_{\text {tabel }}=2,201$ dengan $\alpha=0.05$. Maka Ha diterima dan Ho ditolak. Hal ini membuktikan adanya peningkatan daya ledak otot lengan pemain bolavoli SMA Model Negeri 04 Mukomuko sesudah diberikan 18x perlakuan menggunakan latihan overheadtricep toss. Dengan demikian hipotesis yang diajukan dapat dibuktikan. Artinya latihan overheadtricep toss berpengaruh terhadap peningkatan daya ledak otot lengan pemain bolavoli SMA Model Negeri 04 Mukomuko.

\section{Pembahasan}

Latihan overhead tricep toss adalah salah satu bentuk latihan pliometrik, khususnya untuk meningkat daya ledak otot lengan. Latihan ini dilakukan dengan cara menggenggam bola dengan satu tangan lurus di samping kepala, setelah itu bengkokan lengan sehingga siku mengarah lurus kedepan dan tegak lurus terhadap tanah dimana bola berada dibelakang kepala, kemudian luruskan lengan secepat mungkin dan lempar bola ke udara dengan hanya menggunakan otot tricep.

Berdasarkan hasil pengujian hipotesis membuktikan bahwa latihan overhead tricep toss dapat memberikan pengaruh secara signifikan terhadap peningkatan daya ledak otot lengan pemain bolavoli SMA Model Negeri 04 Mukomuko, hal ini dapat dilihat dari perbedaan nilai rata-rata (mean) pada tes awal sebelum diberi perlakuan latihan overhead tricep toss yaitu sebesar 3.8 dan setelah diberikan perlakuan diperoleh nilai rata-rata (mean) sebesar 4.3, artinya ada peningakatan sebesar 0.5 meter. Setelah dilakukan analisis data terhadap hasil penelitian dengan menggunakan uji $-\mathrm{t}$ test ditemukan $\mathrm{t}_{\text {hitung }}=15,923>\mathrm{t}_{\text {tabel }}=2,201$ dengan $\alpha=0.05$.

Berdasakan hasil tersebut dapat disimpulkan bahwa latihan overhead tricep toss dengan memberikan latihan sebanyak 18 kali perlakukan dengan frekuensi 4 kali seminggu, ternyata memberikan pengaruh secara signifikan terhadap peningkatan daya ledak otot lengan pemain bolavoli SMA Model Negeri 04 Mukomuko. Hal ini mungkin disebabkan karena : 1) Pelaksanaan latihan dilakukan dengan cara menggenggam bola dengan satu tangan lurus di samping kepala, setelah itu bengkokan lengan sehingga siku mengarah lurus kedepan dan tegak lurus terhadap tanah dimana bola berada dibelakang kepala, kemudian luruskan lengan secepat mungkin dan lempar bola ke udara dengan hanya menggunakan otot tricep, bola yang dilempar adalah seberat $2 \mathrm{~kg}$, 2) Jumlah latihan dilakukan 18 kali, dengan frekuensi 4 kali seminggu dengan penambahan set dalam latihan serta repetisinya disesuaikan dengan kemampuan maksimum yang dimiliki pemain, sehingga dengan latihan tersebut memberikan efek terhadap peningkatan daya ledak otot lengan pemain bolavoli SMA Model Negeri 04 Mukomuko.

Dengan demikian perlu kiranya menjadi perhatian pelatih bolavoli SMA Model Negeri 04 Mukomuko untuk dapat meningkatkan lagi daya ledak otot lengan pemain, diantaranya memberikan bentuk latihan overhead tricep toss secara terprogram dan secara kontinu, karena dari hasil penelitian bentuk latihan ini dapat meningkatkan daya ledak otot lengan.

\section{KESIMPULAN}

Berdasarkan hasil penelitian tentang pengaruh latihan overhead triceptoss terhadap peningkatan daya ledak otot lengan pemain bolavoli SMA Model Negeri 04 Mukomuko, dapat diambil kesimpulan bahwa latihan overhead tricep memberikan pengaruh terhadap peningkatan daya ledak otot lengan pemain bolavoli SMA Model Negeri 04 Mukomuko, yang dibuktikan dengan nilai $\mathrm{t}_{\text {hitung }}=15,923>\mathrm{t}_{\text {tabel }}=2,201$ dengan $\alpha=0.05$. Berdasarkan kepada kesimpulan yang telah dikemukakan di atas, maka disarankan kepada; Pelatih. agar dapat memberikan latihan overhead 
tricep secara terprogram sebagai salah satu cara untuk meningkatkan peningkatan daya ledak otot lengan pemain bolavoli SMA Model Negeri 04 Mukomuko, Pemain, agar melakukan latihan overhead tricep dengan serius, rajin serta disiplin. Peneliti lain, agar dapat meneliti dengan jumlah sampel yang lebih banyak.

\section{DAFTAR RUJUKAN}

Arikunto, Suharsimi. 2010. Prosedur Penelitian. Jakarta : PT Rineka Cipta

David Sandler, McNeely. 2007. Power Plyometrics The Complete Program.

Erianti, 2011. Buku Ajar Bolavoli. Padang: FPOK IKIP.

Ismaryati. 2006. Tes Pengukuran Olahraga. Surakarta: Sebelas Maret University Press.

Johnson, Barry L, J.K Nelson. 1986. Practical Measurements for evaluation in Physical Education. Champaign, IL : Human

PBVSI. 2005. Peraturan Permainan Bolavoli. Jakarta: Gedung Voli Senayan

Undang-Undang RI No.3 Tahun 2005. Tentang Sistem Keolahragaan Nasional. Bandung: Citra Umbara.Singapore : Meyer \& Meyer Sport 